\title{
UPAYA MENINGKATKAN MOTIVASI BELAJAR SISWA MELALUI PEMBERIAN PENGUATAN PADA POKOK BAHASAN SEGITIGA KELAS VII PI MTS PONDOK PESANTREN MARDHATILLAH TANO PONGGOL KECAMATAN ANGKOLA BARAT
}

\author{
Oleh: \\ Desi Efri Kamala \\ Dr. Lelya Hilda, M.Si
}

\begin{abstract}
The lack of students' learning mathematic motivation at Grade VII PI MTs Pondok Pesantren Mardhatillah Tano Ponggol, during learning process because the method that uses by teacher is conventional method that make students' learning motivation is law. So that, very important to make a change in implementation the learning in the class, one of them with giving reinforcement to make the students' to be active in learning process.

The formulation of the problem in this research is wether giving reinforcement can increase students' learning motivation on triangle fundamental discussion at Grade VII PI MTs Pondok Pesantren Mardhatillah Tano Ponggol, Angkola Barat subdistrict. Whereas, the purpose of this research is to know whether giving reinforcement can increase students' learning motivation on triangle fundamental discussion at Grade VII PI MTs Pondok Pesantren Mardhatillah Tano Ponggol Angkola Barat subdistrict.

This research is Classroom Action Research (CAR) collaborates with course teacher. The location of this research in MTs Pondok Pesantren Mardhatillah Tano Ponggol Angkola Barat subdistrict.Which the sample is class VII PI that consist of 28 students'. Instrument of collecting data that uses begin from planning, action, monitoring and reflection. This research do in 2 cycles, each cycles are 2 meeting.

The result of this research shows that $\mathrm{H}_{\mathrm{a}}$ is accepted is there is significant effect or raising of students' learning mathematic motivation through giving reinforcement on triangle fundamental discussion at grade VII PI MTs Pondok Pesantren Mardhatillah Tano Ponggol, Angkola Barat subdistrict. Each observation is meanscore of students' learning mathematic motivation on the first cycle is $50,3 \%$ is increase on the second cycle with meanscore is $73,89 \%$, raising that happen is $23,59 \%$. Whereas, raising gets on questionnaire is refer to meanscore of students learning mathematic motivation on the first cycle is $68,93 \%$ is increase on the second cycle with meanscore is $76,07 \%$, raising that happen is $7,14 \%$.
\end{abstract}

Keyword : Giving Reinforcement, Motivation, Triangle. 


\begin{abstract}
Abstrak
Permasalahan dalam penelitian ini adalah rendahnya motivasi belajar matematika siswa selama proses pembelajaran disebabkan cara yang digunakan guru lebih sering dengan metode ceramah. Sehingga perlu melakukan perubahan dalam pelaksanaan pembelajaran di kelas, salah satunya dengan pemberian penguatan agar siswa ikut aktif dalam pembelajaran.

Adapun tujuan penelitian ini adalah untuk mengetahui proses pemberian penguatan dalam meningkatkan motivasi belajar siswa pada pokok bahasan segitiga di kelas VIIPI MTs Pondok Pesantren Mardhatillah Tano Ponggol Kecamatan Angkola Barat.

Penelitian ini merupakan Penelitian Tindakan Kelas (PTK) kolaborasi dengan guru mata pelajaran. Penelitian ini dilaksanakan di MTs Pondok Pesantren Mardhatillah Tano Ponggol Kecamatan Angkola Barat. Dengan subjek penelitian kelas VII PI yang berjumlah 28 orang. Instrumen pengumpulan data yang digunakan adalah observasi dan angket. Analisis data yaitu analisis data kualitatif. Prosedur PTK dimulai dari tahap perencanaan, tindakan, pengamatan dan refleksi. Penelitian ini dilaksanakan dalam 2 siklus, setiap siklus 2 kali pertemuan.

Hasil penelitian ini menunjukkan bahwa hipotesis tindakan diterima yaitu adanya peningkatan motivasi belajar matematika siswa melalui pemberian penguatan pada pokok bahasan segitiga di kelas VII PI MTs Pondok Pesantren Mardhatillah Tano Ponggol Kecamatan Angkola Barat. Pada setiap observasi yaitu rata-rata motivasi belajar matematika siswa pada prasiklus $27,82 \%$ meningkat pada siklus I 50,3\% peningkatan yang terjadi adalah $22,48 \%$, rata-rata motivasi belajar matematika siswa siklus I 50,3\% meningkat pada siklus II dengan rata-rata $73,89 \%$ peningkatan yang terjadi adalah $23,59 \%$. Sedangkan peningkatan yang terdapat dalam angket adalah dilihat dari rata-rata motivasi belajar matematika siswa pada siklus I 68,93\% meningkat padas iklus II dengan rata-rata $76,07 \%$ peningkatan yang terjadi adalah $7,14 \%$.
\end{abstract}

Kata Kunci: Pemberian Penguatan, Motivasi, Segitiga.

\title{
A. Pendahuluan
}

Pada hakikatnya belajar adalah proses transaksi atau interaksi antar struktur potensi diri dengan guru atau sesuatu sehingga terjadi proses internalisasi atau personalisasi sesuatu serta tercipta perubahan diri. Belajar juga merupakan proses kegiatan internalisasi sesuatu sehingga terjadi perubahan diri tidak tahu menjadi tahu, dari tidak bisa menjadi bisa. ${ }^{1}$

Belajar matematika berkaitan dengan apa dan bagaimana

${ }^{1}$ Hamid Darmadi, Dasar Konsep Pendidikan Moral Landasan Konsep Dasar dan Implementasi (Bandung: Alfabeta, 2012), hlm. 108. 
menggunakan dalam membuat keputusan untuk memecahkan masalah, matematika melibatkan pengamatan, penyelidikan, dan keterkaitan dengan fenomena fisik dan sosial. Sedangkan karakteristik matematika terletak pada kekhususan dalam mengkomunikasikan ide matematika melalui bahasa numerik. Apabila siswa mampu menaruh ide-ide mereka ke dalam kata-kata matematis, maka mereka akan memiliki suatu dasar yang lebih baik tentang cara berpikir mereka. $^{2}$

Dalam mempelajari matematika banyak siswa yang mengalami kesulitan tetapi siswa tersebut tidak berusaha untuk memecahkan bahkan menghindar dari kesulitan yang dihadapinya. Sehingga, menimbulkan rasa tidak senang atau rasa benci terhadap pelajaran matematika.Ini bisa dilihat dari kesungguhan dan keantusiasan siswa dalam mengikuti pelajaran matematika sangat rendah. ${ }^{3}$

Berdasarkan observasi awal yang dilakukan peneliti di Pondok Pesantren Mardhatillah Tano Ponggol diketahui bahwa :

kurangnya motivasi siswa saat proses pembelajaran berlangsung dapat dilihat dari sikap siswa yang ribut di dalam kelas, tidak mendengarkan dan memperhatikan tentang materi yang diajarkan oleh guru saat proses pembelajaran, siswa tidak berani bertanya mengenai materi yang belum mereka mengerti, siswa kurang aktif selama proses pembelajaran berlangsung, siswa yang suka mengganggu siswa lain dalam pembelajaran, rasa ingin tahu siswa terhadap pelajaran tidak ada. $^{4}$

Rendahnya hasil belajar matematika siswa bermula dari tidak adanya minat dan motivasi belajar, siswa terbiasa menerima dan menghapal apa yang diberikan guru tanpa termotivasi untuk memahaminya disebabkan dinginnya sikap guru dalam merespon tingkah laku siswa pada saat pembelajaran.

${ }^{2}$ Hamzah B. Uno dan Masri Kuadrad, Mengelola Kecerdasan dalam Pembelajaran (Jakarta: Bumi Aksara, 2010), hlm. 110.

${ }^{3}$ Erman Suherman, Strategi Pembelajaran Matematika Kontemporer (JICA: UPI, 2001), hlm. 55.

${ }^{4}$ Observasi Peneliti di kelas VII PI Pondok Pesantren Mardhotillah Kamis 31 Maret 2016 pukul 10.15 WIB. 
Demikian halnya dengan keterampilan pemberian penguatan, dimana guru masih belum sepenuhnya menggunakanpemberian penguatan pada saat pembelajaran berlangsung.

Melihat banyaknya masalah yang mengurangi tingkat motivasi siswa, utamanya dalam pembelajaran matematika khususnya materi segitiga, dimana kemampuan siswa dalam memecahkan masalah masih rendah, tidak adanya alat peraga pada saat pembelajaran yang menyebabkan kejenuhan siswa dalam belajar. Maka salah satu cara untuk menjadikan siswa aktif dan menjadikan proses pembelajaran menyenangkan adalah dengan memberikan penguatan kepada siswa sehingga rasa percaya diri siswa semakin bertambah. $^{5}$

\section{Tinjauan Pustaka}

\section{Motivasi Belajar}

Motivasi berasal dari kata "motif" diartikan sebagai daya upaya yang mendorong seseorang untuk melakukan sesuatu, karena motivasi dapat memberi semangat atau dorongan yang luar biasa terhadap seseorang untuk berperilaku dan dapat memberikan arah dalam belajar. ${ }^{6}$ Adapun menurut Mc. Donald dalam buku karangan Mujtahid bahwa motivasi adalah perubahan energi dalam diri seseorang yang ditandai dengan munculnya "feeling" dan didahului dengan tanggapan terhadap adanya tujuan. ${ }^{7}$

Motivasi belajar adalah merupakan faktor psikis yang bersifat nonintelektual.Peranannya yang khas adalah dalam penumbuhan gairah, merasa senang dan semangat untuk belajar. Siswa yang memiliki motivasi kuat, akan mempunyai banyak energi untuk melakukan kegiatan belajar. Seseorang siswa yang memiliki intelegensi cukup tinggi, boleh jadi gagal karena kekurangan

${ }^{5}$ User Usman, Menjadi Guru Profesional (Bandung: Remaja Rosdakarya, 2006), hlm.81.

${ }^{6}$ Sumiati dan Asra, Metode Pembelajaran (Bandung: CV Wacana Prima, 2007), hlm. 236.

${ }^{7}$ Mujtahid, Pengembangan Profesi Guru (Malang: UIN-Maliki Press, 2011), hlm. 119. 
motivasi. Hasil belajar akan optimal kalau ada motivasi yang tepat. Jadi tugas guru bagaimana mendorong para siswa agar pada dirinya tumbuh motivasi. ${ }^{8}$ Motivasi juga merupakan perubahan energi dalam diri (pribadi) seseorang yang ditandai dengan timbulnya perasaan dan reaksi untuk mencapai tujuan.

Dalam membicarakan soal jenis motivasi, hanya akan dibahas dari dua sudut pandang, yakni motivasi instrinsik dan motivasi ekstrinsik. Motivasi instrinsik adalah motivasi yang berasal dari dalam diri individu tanpa adanya rangsangan dari luar, sebagai contoh seseorang yang senang membaca, meski tidak ada yang menyuruh atau mendorongnya, ia sudah rajin mencari buku-buku untuk membacanya. Sedangkan motivasi ekstrinsik adalah kebalikan dari motivasi intrinsik, yaitu motivasi yang berasal dari luar diri individu karena adanya rangsangan dari luar.

\section{Pemberi Penguatan}

Penguatan (reinforcement) adalah segala bentuk respons, apakah bersifat verbal ataupun nonverbal, yang merupakan bagian dari modifikasi tingkah laku guru terhadap tingkah laku siswa, yang bertujuan untuk memberikan informasi atau umpan balik (feedback) bagi si penerima (siswa) atas perbuatannya sebagai suatu tindak dorongan ataupun koreksi. Penguatan juga merupakan respons terhadap suatu tingkah laku yang dapat meningkatkan kemungkinan berulang kembali tingkah laku tersebut. Tindakan tersebut dimaksudkan untuk mengganjar atau membesarkan hati siswa agar mereka lebih giat berpartisipasi dalam interaksi belajar mengajar. ${ }^{9}$

Keterampilan memberikan penguatan merupakan keterampilan yang arahnya untuk memberikan dorongan, tanggapan, atau hadiah bagi siswa agar dalam mengikuti pelajaran merasa dihormati dan diperhatikan. ${ }^{10}$ Penguatan adalah

${ }^{8}$ Sardiman, Interaksi \& Motivasi Belajar Mengajar (Jakarta: Rajawali Pers, 2011), hlm. 75-76.

${ }^{9}$ User Usman, Menjadi Guru Profesional (Bandung: PT Remaja Rosdakarya, 2006), hlm. 80.

${ }^{10}$ Hamzah B. Uno, Orientasi Baru Dalam Psikologi Pembelajaran (Jakarta: Bumi Aksara, 2006), hlm. 168. 
respon terhadap suatu tingkah laku positif yang dapat meningkatkan kemungkinan berulangnya kembali tingkah laku tersebut. ${ }^{11}$

\section{B. Metode Penelitian}

\section{Tempat dan Waktu Penelitian}

Penelitian ini dilaksanakan di Pondok Pesantren Mardhatillah Tano Ponggol yang beralamat di Lingkungan I Tano Ponggol Kelurahan Sitinjak Kecamatan Angkola Barat Tapanuli Selatan Sumatera Utara. Penelitian ini dilaksanakan mulai bulan Mei 2016 sampai Juni 2017.

\section{Jenis Penelitian}

Jenis penelitian yang akan dilakukan adalah penelitian tindakan kelas (Classroom Action Reasearch).

\section{Subjek Penelitian}

Subjek dalam penelitian ini adalah siswa kelas VII-PI MTs Pondok Pesantren Mardhatillah Tano Ponggol, dengan jumlah siswa 28 orang yang terdiri dari 28 orang perempuan.

\section{Instrumen Penelitian}

Adapun instrumen yang digunakan dalam penelitian ini adalah observasi dan angket.

\section{Teknik Analisis Data}

Karena penelitian bersifat kualitatif, maka analisis data berlangsung mulai dari awal penelitian sampai penelitian berakhir yang dituangkan dalam laporan penelitan yang dilakukan secara simultan dan terus-menerus.Analisis data penelitian tindakan kelas mengikuti metode alur. Milles dan Huberman dalam buku Iskandar menyatakan bahwa alur analisis data melalui tiga tahap, yaitu reduksi data, penyajian data (data display), dan penarikan kesimpulan atau verifikasi. ${ }^{12}$

${ }^{11}$ Zainal Asril, Micro Teaching Disertai dengan Pedoman Pengalaman Lapangan (Jakarta: Rajawali Pers, 2012), hlm. 77.

${ }^{12}$ Ibid., 


\section{Hasil Pembahasan Penelitian}

Motivasi belajar adalah suatu kesiapan untuk melakukan pembelajaran karena didorongan oleh keinginannya untuk memenuhi kebutuhan dari dalam dirinya ataupun yang datang dari luar. Kegiatan itu dilakukan secara terusmenerus dengan kesungguhan hati dalam rangka mencapai tujuan.

Hasil penelitian menunjukkan, motivasi belajar matematika siswa kelas VII PI MTs Pondok Pesantren Mardhatillah mengalami peningkatan saat dilaksanakan pembelajaran matematika dengan menggunakan pemberian penguatan. Hal ini tampak dari proses pembelajaran yang dilakukan guru dengan mendorong siswa agar memiliki motivasi yang kuat serta jika siswa tidak memperhatikan penjelasan guru dan tidak mengerjakan tugas maka akan diberi sanksi, dilihat dari hasil pemberian angket pertama dan kedua pada siklus I siswa masih kurang termotivasi kemudian guru terus berusaha untuk meningkatkan motivasi siswa sehingga pada pemberian angket pertama dan kedua pada siklus II motivasi siswa mulai meningkat. Hasil belajar siswa juga mengalami peningkatan dari siklus I hingga siklus II.

Ditinjau dari proses pembelajaran, sebagian besar siswa aktif mengikuti kegiatan pembelajaran yang dilakukan. Siswa belajar secara individu/perorangan dan kelompok diskusi. Pada pembelajaran secara perorangan/individu, siswa masih banyak yang tidak aktif dan ikut andil dalam pembelajaran, siswa juga tidak berani bertanya, mengeluarkan pendapat, dan tidak tertarik serta kurangnya minat pada saat pembelajaran berlangsung. Namun, melalui diskusi kelompok, siswa dilatih untuk bertanya, menanggapi/berpendapat, bekerjasama, menemukan keputusan dang menghargai pendapat orang lain.

Dalam pembelajaran, diadakan pembelajaran melalui pemberian penguatan untuk meningkatkan motivasi belajar siswa dan menciptakan suasana pembelajaran yang menarik dan menyenangkan. Suasana pembelajaran yang menarik akan membuat pembelajaran lebih bermakna secara efektif dan emosional bagi siswa. Sesuatu yang bermakna akan lestari diingat, dipahami dan dihargai.

Pada saat pembelajaran menggunakan penguatan, maka siswa akan merasa senang dan berbesar hati untuk lebih giat berpartisipasi dalam interaksi pada saat 
pembelajaran. Dengan pemberian penguatan, siswa tidak akan merasa takut untuk bertanya, menanggapi/berpendapat pada saat pembelajaran yang membuat suasana pembelajaran seperti kompetisi antar siswa untuk belajar lebih baik dan giat lagi. Persaingan antar siswa akan memberikan kesempatan untuk mengukur dirinya sendiri melalui kemampuan orang lain dan akan menimbulkan upaya belajar yang sungguh-sungguh.

Pembelajaran melalui pemberian penguatan siswa diberikan berbagai macam penguatan tergantung kemampuan siswa, karya, situasi dan peringkat yang di capai. Berdasarkan analisa data hasil observasi, motivasi belajar siswa kelas VII PI MTs Pondok Pesantren Mardhatillah mengalami peningkatan. Dari hasil analisa lembar observasi motivasi belajar, menunjukkan banyaknya siswa yang termotivasi pada saat pembelajaran mencapai 78,57\%. Selain itu berdasarkan hasil angket motivasi belajar, siswa yang berkategori tinggi pada setiap aspek motivasi mencapai lebih dari $70 \%$. Hasil angket disajikan dalam tabel berikut:

Tabel 4. 15

Perbandingan Hasil Angket Motivasi Belajar Siswa Pada Siklus I dan II

\begin{tabular}{|l|c|c|}
\hline \multirow{2}{*}{ Aspek Motivasi } & \multicolumn{2}{c|}{$\begin{array}{c}\text { Banyaknya siswa yang } \\
\text { berada dalam kategori } \\
\text { tinggi (\%) }\end{array}$} \\
\cline { 2 - 3 } & $\begin{array}{c}\text { Siklus I } \\
\text { Siklus II }\end{array}$ \\
\hline Siswa tekun mengerjakan tugas dari guru & 67,86 & 75 \\
\hline Siswa ulet dalam mengerjakan soal yang sulit & 67,86 & 69,64 \\
\hline $\begin{array}{l}\text { Siswa lebih senang untuk mengerjakan soal secara } \\
\text { mandiri }\end{array}$ & 73,21 & 82,14 \\
\hline $\begin{array}{l}\text { Siswa tertarik dengan kegiatan pembelajaran yang } \\
\text { diadakan guru }\end{array}$ & 67,86 & 78,57 \\
\hline Siswa dapat mempertahankan pendapatnya & 67,86 & 75 \\
\hline
\end{tabular}

Berdasarkan hasil angket, banyaknya siswa yang mencapai kategori tinggi pada kedelapan aspek motivasi telah memenuhi indikator keberhasilan. 


\section{Penutup}

1. Kesimpulan

Berdasarkan hasil penelitian yang dilaksanakan sebanyak dua siklus, data di lapangan menunjukkan bahwa, "Upaya Meningkatkan Motivasi Belajar Siswa Pada Pokok Bahasan Segitiga Melalui Pemberian Penguatan di Kelas VII PI MTs Pondok Pesantren Mardhatillah Tano Ponggol Kecamatan Angkola Barat".

a. Berdasarkan hasil observasi disetiap akhir pertemuan membuktikan bahwa adanya peningkatan motivasi belajar pada setiap indikator yaitu rata-rata motivasi belajar matematika siswa pada siklus I 50,3\% meningkat pada siklus II dengan rata-rata $73,89 \%$ peningkatan yang terjadi adalah23,59\%.

b. Berdasarkan hasil angket membuktikan bahwa adanya peningkatan motivasi belajar yang dilihat dari rata-rata yang diperoleh pada siklus I adalah $68,93 \%$ meningkat pada siklus II rata-rata $76,07 \%$ peningkatan yang terjadi adalah $7,14 \%$.

2. Saran

Berdasarkan hasil penelitian, maka peneliti menyarankan:

a. Bagi kepala sekolah khususnya para guru matematika, diharapkan untuk dapat menggunakan pemberian penguatan ini dalam pembelajaran, berdasarkan hasil penelitian terlihat bahwa pemberian penguatan dapat meningkatkan motivasi belajar matematika siswa.

b. Bagi siswa, diharapkan lebih giat dan aktif terlibat langsung dalam mengikuti pembelajaran matematika melalui pemberian penguatan dalam meningkatkan belajarnya baik secara individual ataupun kelompok.

c. Bagi peneliti selanjutnya agar melakukan penelitian yang sama yaitu dengan menggunakan pemberian penguatan dengan materi yang berbeda. 


\section{DAFTAR PUSTAKA}

Azis Saefuddin, Meningkatkan Profesionalisme dengan PTK, Yogyakarta: Citra Aji Parama, 2012.

Ahmad Sabri, Strategi Belajar Mengajar dan Micro Teaching, Jakarta: Quantum Teaching, 2005.

Aunurrahman, Belajar dan Pembelajaran, Bandung: Alfabeta, 2013.

Buchari Alma, Guru Profesional Menguasai Metode dan Terampil Mengajar, Bandung: Alfabeta, 2012.

Dimyati, Belajar dan Pembelajaran, Jakarta: Rineka Cipta, 2009.

Djaali, Psikologi Pendidikan, Jakarta: Bumi Aksara, 2011.

Erman Suherman, Strategi Pembelajaran Matematika Kontemporer, JICA: UPI, 2001.

,dkk. Strategi Pembelajaran Matematika Kontemporer, Bandung: Universitas Pendidikan Indonesia, 2003.

Eveline Siregar \& Hartini Nara, Teori Belajar dan Pembelajaran, Bogor: Ghalia Indonesia, 2010.

Hamid Darmadi, Dasar Konsep Pendidikan Moral Landasan Konsep Dasar dan Implementasi, Bandung: Alfabeta, 2012.

Hamzah B. Uno dan Nurdin Mohammad, Belajar dengan Pendekatan PAILKEM: Pembelajaran Aktif, Inovatif, Lingkungan, Kreatif, Efektif, Menarik, Jakarta: PT Bumi Aksara, 2011.

Hamzah B. Uno dan Masri Kuadrad, Mengelola Kecerdasan dalam Pembelajaran, Jakarta: Bumi Aksara, 2010.

Hamzah B. Uno, Orientasi Baru Dalam Psikologi Pembelajaran, Jakarta: Bumi Aksara, 2006.

Hasratuddin, Mengapa Harus Belajar Matematika?, Medan: Perdana Publishing, 2015.

Iskandar, Penelitian Tindakan Kelas, Jakarta: Referensi , 2012.

Joko Subagyo, Metode Penelitian Dalam Teori dan Praktek, Jakarta: Rineka Cipta, 2004. 
Moh. Uzer Usman, Menjadi Guru Profesional, Bandung: Remaja Rosdakarya, 2006.

Mujtahid, Pengembangan Profesi Guru, Malang: UIN-Maliki Press, 2011.

Mulyasa, Menjadi Guru Profesional: Menciptakan Pembelajaran Kreatif dan Menyenangkan, Bandung: Remaja Rosdakarya, 2008.

Ngapiningsih, dkk, Detik-Detik Ujian Nasional Matematika SMP/MTs, Intan Pariwara: Klaten, 2015.

Nurhabibah, "Penggunaan Metode Plantet Question dalam Meningkatkan Motivasi Belajar Siswa Pada Pokok Bahasan Lingkaran di Kelas VIII MTsN Marenu" (Skripsi, IAIN Padangsidimpuan, 2015.

Oemar Hamalik, Proses Belajar Mengajar, Jakarta: Bumi Aksara, 2001.

Rangkuti, Ahmad Nizar, Metode Penelitian Pendidikan, Bandung: Cipta Pustaka Media, 2014.

Riduwan, Skala Pengukuran Variabel-variabel Penelitian, Bandung: Alfabeta, 2010.

Rizky Anhari Sitompul, dengan judul: "Efektivitas Penerapan Reinforcement Pada Pembelajaran Matematika Di SMP NEGERI 8 Padangsidimpuan tahun ajaran 2014/2015”, skripsi IAIN Padangsidimpuan, 2015.

Sardiman, Interaksi dan Motivasi Belajar Mengajar, Jakarta: Rajawali, 1986.

—, Interaksi \& Motivasi Belajar Mengajar, Jakarta: Rajawali Pers, 2011.

Siti Hardiana Harahap, dengan judul: “ Pengaruh Keterampilan Guru dalam Menjelaskan Pelajarandan Keterampilan Memberikan Penguatan terhadap Motivasi Belajar Matematika pada Siswa Kelas IX MTs Mukhtariyah Gunung Raya Kecamatan Portibi tahun ajaran 2014/2015”, Skripsi IAIN Padangsidimpuan, 2015.

Sugiyono, Penelitian Pendidikan Pendekatan Kuantitatif, Kualitatif, dan R\&D, Bandung: Alfabeta, 2009.

Suharsimi Arikunto, Dasar-Dasar Evaluasi Pendidikan, Jakarta: Bumi Aksara, 1993.

Suharsimi Arikunto dan Cefi Saffruddin Abdul Jabar, Evaluasi Program Pendidikan, Jakarta: Bumi Aksara, 2004.

Suharsimi Arikunto, Dasar-Dasar Evaluasi Pendidikan, Jakarta: Bumi Aksara, 2006. 
---------------, Penelitian Tindakan Kelas , Jakarta: Bumi Aksara, 2007.

Sumiati dan Asra, Metode Pembelajaran, Bandung: Wacana Prima, 2007.

Syaiful Bahri Djamarah, Psikologi Belajar, Jakarta: Rineka Cipta, 2011.

Udin Syaefuddin Saud, Pengembangan Profesi Guru, Bandung: Alfabeta, 2010.

User Usman, Menjadi Guru Profesional, Bandung: Remaja Rosdakarya, 2006.

Wina Sanjaya, Penelitian Tindakan Kelas, Bandung: Kencana, 2010.

Zainal Asril, Micro Teaching Disertai dengan Pedoman Pengalaman Lapangan, Jakarta: Rajawali Pers, 2012. 